\title{
Providing principled health care in prison
}

$\mathrm{E}$ thical considerations are often lost in the heated rhetoric that typically emerges in debates about the treatment of the incarcerated. But having deprived prisoners of their freedom and the ability to access their own health care, society has an obligation to provide them basic health necessities. What exactly those are, and how and whether they are provided, is another issue altogether.

In Canada, there is a legal obligation on the state to provide health services for inmates. In the case of those incarcerated in federal institutions, the Correctional Service of Canada (CSC) is compelled by the Correctional and Conditional Release Act to provide "essential" health care and reasonable access to nonessential mental health care services, while contributing to rehabilitation and successful reintegration to society upon release, says Sara Parkes, a spokesperson for CSC.

The standards of care "shall conform to professionally accepted standards" and "shall take into consideration an offender's state of health and health care needs," according to sections 86 and 87 of the act.

Those needs refer to "all decisions affecting the offender, including decisions relating to placement, transfer administrative segregation and disciplinary matters; and in the preparation of the offender for release and the supervision of the offender."

But there is considerable room for interpretation regarding what exactly constitutes "essential health care" and there are those who believe that events such as 2007 suicide of Ashley Smith, which is now the subject of a public inquiry, indicate there is a wide discrepancy between what the average person might perceive to be essential, and what the prison system considers essential.

That ambiguity may be even more widely expressed in the United States, even though there have been several judicial decisions that have outlined the state's responsibilities to provide health

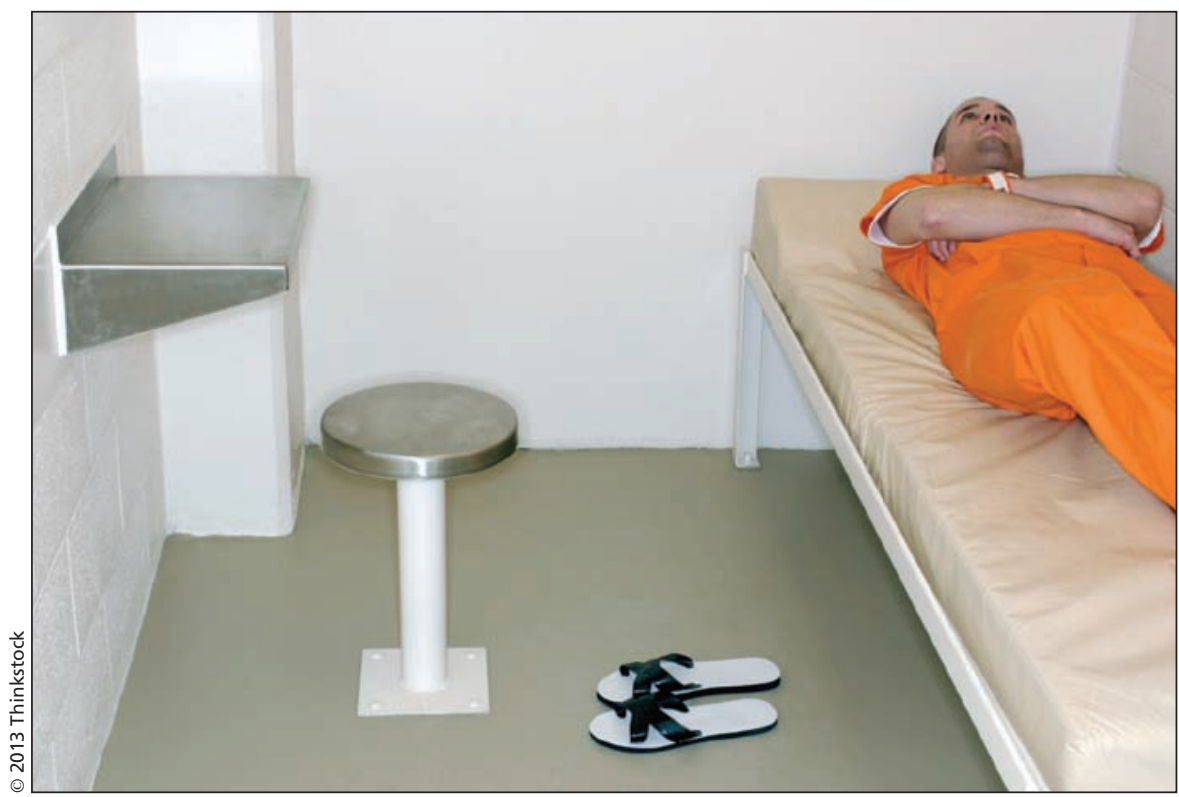

Being caged puts prisoners in a vulnerable position with regard to their health care, experts say.

care, and the level to which it must be provided.

That may, in part, be the product of a culture that incarcerates its citizens at a rate roughly five times higher than Canada. There are now more than 2.2 million Americans in prison, as compared with roughly 40000 in Canadian prisons or jails at any given moment in time.

Volume alone affects the provision of care, experts say.

"We have an epidemic of incarceration," notes Dr. Josiah D. Rich, professor of medicine and epidemiology at the Warren Alpert Medical School at Brown University in Providence, Rhode Island. "We have a much bigger problem with incarceration in this country than anywhere else, at any other time. We incarcerate a greater proportion of our population than any country, any civilization, has ever incarcerated anybody."

Rich notes that a landmark US Supreme Court ruling explicitly stated that there is an ethical and constitutional obligation to provide health care to prisoners because failure to do so would be cruel and unusual punishment (Estelle v Gamble, www.law.cornell.edu/supct /html/historics/USSC_CR_0429_0097 ZZO.html).

The reality, though, is that the ethical obligation is often lost in the dayto-day gristmill of prison life, Rich says. "Health care has sort of taken a backseat to the public safety mission," he notes. "The mission of an institution is to keep people locked up or maybe to rehabilitate them, maybe to punish them. We haven't quite figured that out in this country. But health care has not been seen and not widely regarded as a primary mission of the institution."

Compounding the problem is that prison itself exposes people to more communicable diseases and its harshness contributes to higher prevalence of mental illness and drug abuse.

The upshot is that inmates are a "very ill population" in comparison with those outside the walls and that, Rich argues, is a "failing of the medical profession and health professions in general," because of the legal and societal obligation to provide for the care and well-being of prisoners. 
Being caged puts prisoners in a vulnerable position with regard to their health care, says Dr. Robert Greifinger, a prison health care consultant who was responsible for medical care at Rikers Island prison in the middle of the East River in New York City during the 1980s. "Prisoners are different from other people in that they are locked up and that they don't have choices," says Greifinger, who later became chief medical officer for the New York state prison system. "They don't have the choice to go to a doctor or to go to an emergency room. ... They're entirely dependent on the institution to provide for their basic needs."

"From a human rights point of view, prisoners need to be provided for, they need to get medical care that is consistent with what they need," Greifinger adds. "They don't need to have all the fancy flourishes and options and elective care that some of us in the free world might choose to buy, but in terms of meeting their basic medical needs from a human rights perspective, they need access to medical care."

Basic care is a basic human right, adds Joseph Amon, an epidemiologist and director of the Health and Human Rights Division at the watchdog charity Human Rights Watch. "That includes living conditions, it includes providing food and it includes providing health care and if they are unable to provide basic conditions in those categories ... the courts intervene and say that they have to release people. They can't hold them in inhumane conditions."

Internationally, the United Nations has also established standards for the treatment of prisoners that are supposed to guide the provision of health services to inmates (http://www2.ohchr.org/english /law/treatmentprisoners.htm).

In Europe, the ethical obligation to provide health care to inmates was laid out in the European Prison Rules, which were formulated with help from the Council of Europe, the European Committee for the Prevention of Torture and Inhman or Degrading Treatment of Punishment, the World Medical Association, the International Council of Nurses, the World Health Organization and the Swiss Academy of Medical Sciences (www.cpt.coe.int/en/documents /eng-standards.pdf). Those rules are built on seven principles: "access to a doctor, equivalence of care, patient's consent and confidentiality, preventive health care, humanitarian assistance, professional independence and professional competence."

Society has a civic responsibility to provide quality care to inmates because "the prison population is not equivalent to the general one," says Dr. Slim Slama, a clinician and assistant professor in the Division of International and Humanitarian Medicine at the University Hospitals of Geneva, Switzerland. "Because usually these are very vulnerable people from various perspectives; such as socioeconomic factors, addictions, and all the problems that they have are really not comparable to the general population."

Slama has argued that being

Editor's note: Fifth of a multipart series on health in the hoosegow.

Part I: Health and hard time (www.cmaj.ca/lookup/doi/10.1503/cmaj.109-4389).

Part II: Imprisoning the mentally ill (www.cmaj.ca/lookup/doi/10.1503/cmaj.109-4390).

Part III: Agony behind bars (www.cmaj.ca/lookup/doi/10.1503/cmaj.109-4391).

Part IV: Black eyes and barriers (www.cmaj.ca/lookup/doi/10.1503/cmaj.109-4392). 